\title{
The Oxidative Stress Response of Mirabilis jalapa to Exhausted Engine Oil (EEO) during Phytoremediation
}

\author{
Sadia Tabassum $^{1}$, Naeem Shahid ${ }^{2 *}$, Jin Wang ${ }^{3 * *}$, Muhammad Shafiq ${ }^{1}$, \\ Mehvish Mumtaz ${ }^{1}$, Muhammad Arslan ${ }^{4}$ \\ ${ }^{1}$ College of Earth and Environmental Sciences, University of the Punjab, Lahore \\ ${ }^{2}$ Department of Environmental Sciences, COMSATS Institute of Information Technology, Vehari, Pakistan \\ ${ }^{3}$ College of Agriculture and Biology, Shanghai Jiao Tong University, Shanghai 200240, China \\ ${ }^{4}$ Petroleum Engineering and Geosciences Department, King Fahd University of Petroleum and Minerals, \\ Dammam, Saudi Arabia
}

Received: 19 January 2016

Accepted: 25 February 2016

\begin{abstract}
The current study elucidates the responses of a typical ornamental plant Mirabilis jalapa to exhausted engine oil (EEO) during phytoremediation. Greenhouse experiments were established to assess the plant's response in terms of germination, biomass, chlorophyll content, superoxide dismutase (SOD) activity, catalase activity, soluble protein content, and hydrocarbon degradation at different concentrations of EEO ( 0.5 to $15 \mathrm{~mL}$ ). Results illustrate that the increasing concentration of EEO reduced plant growth, whose responses were further confirmed by decreased chlorophyll content (chlorophyll a and b), high superoxide dismutase activity, lowered catalase activity, and reduced soluble protein content. Although the germination rate was successful in all the treatments, we observed a significant reduction in biomass - especially the elongation inhibition rate $(>48.4 \%)$ - at EEO concentrations higher than $2 \%$. Conclusively, the high toxicity index $(40.4 \%$ to $93.3 \%)$ and lesser hydrocarbons degradation $(36 \%$ to $10.8 \%)$ render the plant species unsuitable for future EEO phytoremediation experiments.
\end{abstract}

Keywords: catalase activity, soluble protein content, superoxide dismutase (SOD) activity, hydrocarbon degradation, chlorophyll content

\section{Introduction}

Over the last two decades, expansion in the petroleum industry has resulted in high production of petrochemical

*e-mail: naeemshahid@ciitvehari.edu.pk

**e-mail: wangjin100@sjtu.edu.cn waste [1-2]. According to a survey, more than $60 \%$ of the total waste generated from heavy machinery is due to exhausted engine oil (EEO); while 24 million tons of EEO is being produced every year globally [3-5]. This high production of EEO is of great concern due to its severe toxic nature of having polycyclic aromatic hydrocarbons. Resultantly, its concentration above a certain level in the environment can be extremely carcinogenic, mutagenic, teratogenic, and/or toxic to plants and other organisms 
[6-7]. Moreover, as plants reside at the lower ranks in the food chain, their bioaccumulation can lead to severe toxicity in tertiary consumers, including humans [8-9]. Therefore, once entered in the human bodies through the food chain, many of these compounds can result in renal disorders, liver diseases, and alteration in DNA [1, 10]. Besides, the presence of EEO in soil can also disturb soil ecology, soil fertility, and alteration of soil structure leading to crop contamination [11].

Recently, phytoremediation has been proven to be one of the best and most cost-effective technologies for restoring the contaminated environment [12-13]. However, the overall success of phytoremediation has remained limited in several ways [14]. One reason behind this limitation is less understanding of plant response to contamination. It has been suggested that the study of plant tolerance during the phytoremediation processes may serve as an important feature toward decontamination [15]. In this regard, many studies have been conducted to evaluate the plant response in terms of traditional growth parameters (root length, shoot length, and dry weight) and biochemical/molecular analysis [16-17]. The research conducted on biochemical assays appears to be promising for better understanding of plant responses to toxic environments [18].

The application of bioassays in phytotoxicity assessment has gained widespread attention in the last 20 years. One way of assessing these phytotoxic responses is by measuring the production of reactive oxygen species (ROS), as they are regulated by biotic and abiotic stresses [19]. Enhanced generation of ROS deteriorates the cell redox status [20] - especially by damaging biological molecules (nucleotides, proteins, carbohydrates, fatty acids, etc.) and membrane structures by induction reactions [21]. As ROS accumulation is chemically toxic, plants exhibits antioxidative mechanisms and a number of enzymatic processes, e.g., superoxide dismutase activity, catalase activity, etc. Superoxide dismutase (SOD) lead to the reduction of oxygen $\left(\mathrm{O}_{2}\right)$ to hydrogen peroxide $\left(\mathrm{H}_{2} \mathrm{O}_{2}\right)$, which is subsequently reduced to water $\left(\mathrm{H}_{2} \mathrm{O}\right)$ by catalases [22]. Therefore, the extent of abiotic stress is indicated by these enzymatic and buffering processes. The current study was conducted to investigate the hypothesis that EEO exposure to 4 O'clock (Mirabilis jalapa) causes an oxidative stress response during phytoremediation. Precisely, the objectives of the current study are to:

1. Study the germination potential of the plant (Mirabilis jalapa).

2. Ascertain plant growth parameters.

3. Investigate the physiological responses in terms of biochemical assays in the presence of different EEO concentrations.

\section{Materials and Methods}

\section{Experimental Design}

A total of $20 \mathrm{~L}$ of EEO was obtained from two sites in Lahore, i.e. Khan Autos in Iqbal Town and the LTV EEO changing station in Garden Town. For the pot experiments, agricultural loamy soil $(\mathrm{pH} 7.1$, electrical conductivity $1,093.3 \mu \mathrm{S} \mathrm{cm}^{-3}$, phosphorus $13.75 \mathrm{mg} \mathrm{Kg}^{-1}$, organic matter $1.64 \%$, organic carbon $0.95 \%$, nitrogen $0.003 \%$, sand $50 \%$, silt $37.5 \%$, and clay $2.5 \%$ ), after passing through a $2 \mathrm{~mm}$ sieve and spiking with different concentrations of EEO, was filled into pots $\left(1.5 \mathrm{~kg}\right.$ soil pot $\left.^{-1}\right)$ and subsequently placed in a greenhouse. Mirabilis jalapa was shown to tolerate, extract, and/or sequester a variety of contaminates such as diesel, nitrobenzene, and heavy metals in the previous studies and, hence, was chosen as the host plant [2325]. In order to avoid any issues in germination, certified plant seeds were procured from Punjab Seed Corporation. The phytotoxicity study was examined through seed germination and plant growth as suggested earlier [26-27]. For this purpose, the pre-screening germination test was carried out on the basis of percentage of age germination, and seedlings with poor growth were removed. A total of 66 pots (33 for each plant) were prepared with different concentrations of EEO $(0,0.5,1,1.5,2,3,4,5,7.5,10$, and $15 \mathrm{~mL}$ ) and pots were kept in randomized complete block design (RCBD). Each treatment was further triplicated to minimize the standard error.

\section{Plant Biomass Analysis}

After completion of an incubation period (48 days), plant shoots were cut $1 \mathrm{~cm}$ above ground and roots were separated from soil carefully with washing several times to avoid discrepancies in biomass calculation. The total numbers of leaves were counted, including damaged ones. Afterward, fresh and dry biomass of shoots and roots were estimated as explained previously [28]. Furthermore, plant agronomic characters such as average shoot length and root length were measured using ImageJ software [29]. The selection of plants for the biomass calculation was performed using a ranked set sampling procedure as explained previously [30-31]. Lastly, toxicity index (TI) was calculated to elucidate the EEO stress on plant biomass modifying the given existing formula [32].

Toxicity Index $(T I)=1-\frac{D W \text { biomass yielded in soil ammendments }}{D W \text { biomass yielded in control soil }}$

\section{Residual EEO Analysis}

The soil samples were analyzed before and after cultivation to quantify the residual EEO using FTIR, as explained previously [33].

\section{Plant-Biochemical Analysis}

The biochemical analyses were performed to assess the plant response in terms of chlorophyll content, superoxide dismutase (SOD) activity, catalase activity, and soluble protein content. All of the analyses were limited to $2 \%$ EEO concentration as the higher percentages did not yield required biomass for the analysis. The analyses were based 
on improved methodologies adopted by different authors in earlier studies [34-36].

Chlorophyll Determination: The chlorophyll meter (SPAD-502Plus) was used to estimate the overall chlorophyll content (non-destructive method). Moreover, the individual pigment content was also determined in terms of chlorophyll $\mathrm{a}, \mathrm{b}$, and total content using the destructive method. For this purpose, $250 \mathrm{mg}$ of leaves material were taken and grounded with $1.5 \mathrm{~mL}$ of $80 \%$ ethanol using a mortar and pestle. The resulting homogenate was centrifuged for 15 minutes at $800 \mathrm{rpm}$. Finally, the obtained supernatant was tested in a UV spectrophotometer (UV-1900 BMS), and absorbance was recorded at 645 and $663 \mathrm{~nm}$ as explained previously [37]. The following formulas were used for the calculations:

$$
\begin{gathered}
\text { Chlorophyll a }\left(\mu \mathrm{g} \mathrm{g}^{-1} \mathrm{FW}\right) \\
=\left(12.7 \times \mathrm{A}_{663}-2.69 \times \mathrm{A}_{645}\right) \\
\text { Chlorophyll b }\left(\mu \mathrm{g} \mathrm{g}^{-1} \mathrm{FW}\right) \\
=\left(22.9 \times \mathrm{A}_{645}-4.68 \times \mathrm{A}_{663}\right) \\
\text { Total chlorophyll }\left(\mu \mathrm{g} \mathrm{g}^{-1} \mathrm{FW}\right) \\
=(\text { Chlorophyll } \mathrm{a}+\text { Chlorophyll } \mathrm{b})
\end{gathered}
$$

SOD Determination: For SOD determination, extracts were prepared by homogenizing the plant tissue with $2 \mathrm{~mL}$ of $0.05 \mathrm{M}$ potassium phosphate at $\mathrm{pH} 7.8$, leading to centrifugation at $20,000 \mathrm{~g}$ for 10 minutes. Afterward, the reduction of nitro blue tetrazolium (NBT) was followed at $560 \mathrm{~nm}$ through a spectrophotometer. Briefly, two tubes were used, each having $13 \mathrm{mM}$ methionine, $0.1 \mathrm{mM}$ EDTA, $2 \mathrm{~mL} 1.0 \mathrm{mM}$ sodium cyanide $(\mathrm{NaCN}), 2.0 \mu \mathrm{M}$ riboflavin and $75 \mu \mathrm{M}$ NBT as substrate. One tube was used as a sample having a reaction mixture with $5.0 \mu$ l extract of enzyme while the other tube had a reaction mixture only (without enzyme extract) and was covered with a black cloth. Finally, the absorbance of both illuminated and nonilluminated tubes were compared to assess SOD activity [36].

Catalase Activity Assay: In order to assess the catalase activity, reaction was carried out using two buffer solutions, i.e., $50 \mathrm{mM}$ potassium phosphate $(\mathrm{pH} 7.0)$ as buffer $\mathrm{A}$, and the mixture of $0.036 \% \mathrm{H}_{2} \mathrm{O}_{2}$ solution in $50 \mathrm{mM}$ potassium phosphate as buffer $\mathrm{B}$. The reaction mixture comprised $0.1 \mathrm{~mL}$ of enzyme extract and of $2.9 \mathrm{~mL}$ buffer $\mathrm{B}$, while control consisted of only $3.0 \mathrm{~mL}$ of buffer $\mathrm{A}$. The enzyme activity was measured at $240 \mathrm{~nm}$ as explained earlier [35].

Soluble Protein Content Determination: The plant matter was homogenized with $0.1 \mathrm{M}$ phosphate buffer, which was further centrifuged at $10,000 \mathrm{rpm}$ for 10 minutes. Analyses were conducted on the resulting supernatants. The reaction mixture was comprised of $2 \mathrm{~mL}$ of Biuret reagent and $0.1 \mathrm{~mL}$ of supernatant, whereas control was $0.1 \mathrm{~mL}$ of distilled water. Reading was taken at $545 \mathrm{~nm}$ using a UV-spectrophotometer. The final amount of protein was evaluated from a standard curve of known protein concentration, initially prepared from bovine serum albumin [34].

\section{Statistical Analysis}

Plant biomass, residual EEO estimation, and biochemical results were interpreted using Minitab software (version 16.0). One-way analysis of variance (ANOVA) was used for the comparisons between the treatments considering Kruskal-Wallis test as non-parametric test [38]. Moreover, the cluster analysis (CA) was applied to identify the similarities between different EEO-contaminated treatments. The analysis was based on the Euclidean distance method that produced dendrograms with exceptionally well-defined clusters, where each cluster includes treatments with a similar plant response data.

\section{Results And Discussion}

\section{Plant Biomass}

Growth parameters (i.e., seed germination, root and shoot fresh and dry weights) were determined to assess the effects of different concentrations of EEO on plant development. In the absence of the contaminant, there was significantly more seed germination, shoot length, root length, and plant biomass (root and shoot); however, a gradual decrease was observed with increasing EEO concentrations (Table 1). This could be due to the fact that the presence of high organic carbon content results in changes in physicochemical properties of soil - especially the decreased availability of nutrients and water [3940]. Likewise, higher EEO concentrations resulted in the delay in seed germination, but all of the seedlings were able to survive at the end of the incubation period (data not presented). This could be due to the fact that early seedlings are sensitive to the oxidative stress that was later adopted by the embryo $[15,41]$. Many other studies have also reported the significant reduction of germination at higher concentrations of spent engine oil as well as lubricating oil [42-45].

The highest tolerance level was observed at lower contaminations, whose strength was decreased with increases in the EEO concentration. Agbogidi and Ohwo [46] have also reported a tolerance index of $71.92 \%$ for Jatropha curcas at the lowest pollution level of engine oil, which decreased with increasing concentrations of SEO in soil.

Furthermore, with the increase in EEO concentrations, the total number of leaves was decreased compared to control; and the average damage was high at high EEO concentrations in grown plants compared to the lower EEO concentrations in grown plants (Table 2). Previously, different authors have reported the higher number of leaves in control compared to the other treatments polluted with different concentrations of spent engine oil [42, 47]. 
Table 1. Effects of different exhausted engine oil (EEO) concentrations on seed germination, plant length (shoot and root lengths), plant weight (shoot and root) fresh weights and dry weights after 48 days of sowing.

\begin{tabular}{|c|c|c|c|c|c|c|c|c|}
\hline \multirow[b]{2}{*}{$\begin{array}{l}\text { Treatment } \\
(\% \text { EEO) }\end{array}$} & \multirow{2}{*}{$\begin{array}{c}\text { Seed } \\
\text { Germination } \\
(\%)\end{array}$} & \multicolumn{2}{|c|}{ Plant Length } & \multirow{2}{*}{$\begin{array}{c}\text { Elongation } \\
\text { Inhibition } \\
\text { Rate (EI) } \\
(\%)\end{array}$} & \multirow{2}{*}{$\begin{array}{c}\text { Germination } \\
\text { Index (GI) } \\
(\%)\end{array}$} & \multicolumn{2}{|c|}{ Plant weight } & \multirow{2}{*}{$\begin{array}{l}\text { Toxicity } \\
\text { Index } \\
(\%)\end{array}$} \\
\hline & & $\begin{array}{l}\mathrm{SL} \\
(\mathrm{cm})\end{array}$ & $\begin{array}{l}\mathrm{RL} \\
(\mathrm{cm})\end{array}$ & & & $\begin{array}{l}\text { FW } \\
(\mathrm{g})\end{array}$ & $\begin{array}{l}\text { DW } \\
(\mathrm{g})\end{array}$ & \\
\hline Control & $93.3^{\mathrm{a}}(9.4)$ & $26.5^{\mathrm{a}}(0.41)$ & $8.38^{\mathrm{a}}(0.06)$ & 0 & 100 & $7.75^{\mathrm{a}}(2.87)$ & $0.89^{\mathrm{a}}(0.28)$ & $0^{\mathrm{d}}$ \\
\hline 0.5 & $86.7^{\mathrm{a}}(9.1)$ & $26.1^{\mathrm{a}}(0.35)$ & $7.24^{\mathrm{a}}(0.04)$ & 13.6 & 80.3 & $4.63^{\mathrm{b}}(2.17)$ & $0.51^{\mathrm{b}}(0.24)$ & $42.7^{b}$ \\
\hline 1.0 & $86.7^{\mathrm{ab}}(9.1)$ & $26.3^{\mathrm{a}}(0.31)$ & $7.48^{\mathrm{a}}(0.04)$ & 10.7 & 82.9 & $6.14^{\mathrm{ab}}(2.22)$ & $0.53^{\mathrm{a}}(0.30)$ & $40.4^{c}$ \\
\hline 1.5 & $80.0^{\mathrm{ab}}(0.0)$ & $24.6^{\mathrm{a}}(0.34)$ & $7.91^{\mathrm{a}}(0.05)$ & 5.61 & 80.9 & $4.49^{\mathrm{b}}(0.78)$ & $0.51^{\mathrm{b}}(0.13)$ & $43.7^{\mathrm{b}}$ \\
\hline 2.0 & $73.3^{\mathrm{ab}}(9.4)$ & $22.2^{\mathrm{ab}}(0.52)$ & $8.31^{\mathrm{a}}(0.04)$ & 0.83 & 77.9 & $2.38^{\mathrm{bc}}(0.79)$ & $0.34^{\mathrm{c}}(0.09)$ & $61.8^{\mathrm{ab}}$ \\
\hline 3.0 & $66.7^{\mathrm{ab}}(9.4)$ & $8.03^{\mathrm{bc}}(0.42)$ & $4.32^{\mathrm{b}}(0.05)$ & 48.4 & 36.9 & $1.06^{\mathrm{c}}(0.05)$ & $0.13^{\text {cd }}(0.03)$ & $85.4^{\mathrm{a}}$ \\
\hline 4.0 & $53.3^{\mathrm{b}}(24.9)$ & $12.4^{\mathrm{b}}(0.46)$ & $4.23^{\mathrm{b}}(0.04)$ & 49.5 & 28.8 & $0.91^{\mathrm{c}}(0.17)$ & $0.11^{\text {cd }}(0.03)$ & $87.6^{\mathrm{a}}$ \\
\hline 5.0 & $53.3^{\mathrm{b}}(24.9)$ & $5.30^{\mathrm{bc}}(0.94)$ & $3.64^{\text {bc }}(0.04)$ & 56.5 & 24.8 & $0.65^{\mathrm{c}}(0.12)$ & $0.09^{\mathrm{d}}(0.01)$ & $89.9^{\mathrm{a}}$ \\
\hline 7.5 & $46.7^{\mathrm{b}}(9.4)$ & $6.36^{\mathrm{bc}}(0.75)$ & $3.68^{\mathrm{bc}}(0.03)$ & 56.1 & 22 & $0.56^{\mathrm{c}}(0.22)$ & $0.09^{\mathrm{d}}(0.02)$ & $89.9^{\mathrm{a}}$ \\
\hline 10.0 & $33.3^{\mathrm{bc}}(9.4)$ & $5.86^{\mathrm{bc}}(0.46)$ & $3.13^{\mathrm{c}}(0.03)$ & 62.6 & 13.3 & $0.36^{\mathrm{cd}}(0.09)$ & $0.07^{\mathrm{d}}(0.02)$ & $92.1^{\mathrm{a}}$ \\
\hline 15.0 & $26.7^{\mathrm{bc}}(9.2)$ & $4.36^{\mathrm{bc}}(0.45)$ & $2.92^{\mathrm{c}}(0.03)$ & 65.1 & 10 & $0.32^{\mathrm{cd}}(0.05)$ & $0.06^{\mathrm{d}}(0.02)$ & $93.3^{\mathrm{a}}$ \\
\hline
\end{tabular}

Each value is the mean of three replicates; means in the same column followed by the same letter are not significantly different at a $5 \%$ level of significance; the standard error of three replicates is presented in parentheses.

\section{Chlorophyll Analysis}

Chlorophyll analysis revealed highest chlorophyll in control experiment, whereas lower values were observed

Table 2. Effects of different EEO concentrations on plant damage and chlorophyll reduction.

\begin{tabular}{|c|c|c|c|c|}
\hline \multirow[b]{2}{*}{$\begin{array}{l}\text { Treatment } \\
(\% \text { EEO })\end{array}$} & \multicolumn{2}{|c|}{ Leaves } & \multirow[b]{2}{*}{$\begin{array}{c}\text { Damage } \\
(\%)\end{array}$} & \multirow[b]{2}{*}{$\begin{array}{c}\text { Chlorophyll } \\
\text { (SPAD } \\
\text { Value) }\end{array}$} \\
\hline & $\begin{array}{l}\text { Total } \\
\text { number of } \\
\text { leaves } \\
\text { (n) }\end{array}$ & $\begin{array}{l}\text { Damaged } \\
\text { number } \\
\text { of leaves } \\
\text { (n) }\end{array}$ & & \\
\hline Control & $29.33^{\mathrm{a}} \pm 8.9$ & $1.33^{\mathrm{c}} \pm 1.2$ & 4.5 & $93.3^{\mathrm{a}}(9.4)$ \\
\hline 0.5 & $17.67^{b} \pm 7.3$ & $2.33^{\mathrm{b}} \pm 0.5$ & 13.2 & $86.67^{\mathrm{a}}(8.7)$ \\
\hline 1.0 & $27^{\mathrm{a}} \pm 5.9$ & $2.67^{\mathrm{b}} \pm 0.5$ & 9.9 & $86.67^{\mathrm{ab}}(9.1)$ \\
\hline 1.5 & $29^{\mathrm{a}} \pm 10.7$ & $2.33^{\mathrm{b}} \pm 1.2$ & 8 & $80.01^{\mathrm{ab}}(5.1)$ \\
\hline 2.0 & $15.33^{\mathrm{b}} \pm 2.1$ & $5.33^{\mathrm{a}} \pm 1.7$ & 34.8 & $73.33^{\text {ab }}(7.4)$ \\
\hline 3.0 & $6^{\mathrm{bc}} \pm 0.8$ & $2.33^{\mathrm{b}} \pm 1.2$ & 38.8 & $66.67^{\mathrm{ab}}(6.3)$ \\
\hline 4.0 & $7.33^{\mathrm{bc}} \pm 0.5$ & $2 b^{c} \pm 1.6$ & 27.3 & $53.33^{\mathrm{b}}(3.4)$ \\
\hline 5.0 & $5.33^{\mathrm{bc}} \pm 1.2$ & $3^{\mathrm{b}} \pm 0.8$ & 56.3 & $53.3^{\mathrm{b}}(4.1)$ \\
\hline 7.5 & $3.67^{\mathrm{c}} \pm 1.2$ & $2.33^{b} \pm 0.5$ & 63.5 & $46.67^{\mathrm{b}}(3.3)$ \\
\hline 10.0 & $4^{\mathrm{c}} \pm 0.8$ & $3.33^{\mathrm{b}} \pm 0.9$ & 83.3 & $33.33^{\mathrm{c}}(4.4)$ \\
\hline 15.0 & $2.33^{\mathrm{c}} \pm 0.5$ & $2^{b} \pm 0.8$ & 85.8 & $26.67^{\mathrm{c}}(4.26)$ \\
\hline
\end{tabular}

Each value is the mean of three replicates; means in the same column followed by the same letter are not significantly different at a 5\% level of significance; the standard error of three replicates is presented in parentheses. for $10 \%$ and $15 \%$ EEO grown plants (SPAD values) as shown in Table 2. Similarly, Adenipekun [42] also reported the negative effects of engine oil on the photosynthetic activity of the plants.

\section{Biochemical Analysis}

All the biochemical analyses were performed only up to plants cultivated on $2 \%$ EEO-contaminated soil because the higher concentrations significantly reduced plant biomass (Fig. 1). The significant reduction in biomass could be attributed to the increased production of reactive oxygen species (ROS), whose strength was further increased with increases in biotic and abiotic stresses, i.e., less availability of oxygen, water, nutrients, etc. [19]. It has been well established that the higher pollutant levels can increase the toxic ROS load exceeding the capacity of the plants' antioxidant systems. Resultantly, the excess ROS may cause significant reductions in plant biomass as well as the damage to tissue and organelle structures [26]. Chlorophyll Pigment Analysis: Individual assessment of both pigments (chlorophyll a, chlorophyll b) and total chlorophyll content suggest that highest concentrations of chlorophyll $\mathrm{a}$ and $\mathrm{b}$ were observed in control, whereas the pigment concentration gradually decreased as EEO concentration increased. Moreover, differences in concentrations of chlorophyll a between the first treatment and control is not significant and hence the overall decrease is attributed to the decreasing concentration of chlorophyll b (Table 3). The reduction in chlorophyll pigments is attributed to the hindrances in the metabolic pathway of chlorophyll synthesis, especially by inhibiting 
Table 3. Effects of different EEO concentrations on plant metabolic activities (biochemical analysis).

\begin{tabular}{|c|c|c|c|c|c|c|}
\hline \multirow{2}{*}{$\begin{array}{c}\text { Treatment } \\
(\% \text { EEO })\end{array}$} & \multicolumn{3}{|c|}{ Chlorophyll $\left(\mu \mathrm{g} \mathrm{g}^{-1}\right)$} & \multirow{2}{*}{$\begin{array}{c}\text { SOD Assay } \\
\left(\mu \mathrm{mg}^{-1} \text { protein }\right)\end{array}$} & \multirow{2}{*}{$\begin{array}{c}\text { CAT Assay } \\
\left(\mu \mathrm{mg}^{-1} \text { protein }\right)\end{array}$} & \multirow{2}{*}{$\begin{array}{c}\text { SPC } \\
\left(\mathrm{mg} \mathrm{g}^{-1} \text { protein }\right)\end{array}$} \\
\hline & $\mathrm{a}$ & $\mathrm{b}$ & Total & & & \\
\hline Control & $552.8^{\mathrm{a}}(35.8)$ & $373.4^{\mathrm{a}}(13.6)$ & $926.2^{\mathrm{a}}(10.8)$ & $8.01^{\mathrm{c}}(0.31)$ & $14.55^{\mathrm{a}}(0.74)$ & $15.8^{\mathrm{a}}(0.32)$ \\
\hline 0.5 & $549.3^{\mathrm{a}}(10.7)$ & $314.4^{\mathrm{ab}}(13.7)$ & $863.8^{\mathrm{a}}(15.6)$ & $10.3^{\mathrm{c}}(0.22)$ & $13.95^{\mathrm{a}}(0.85)$ & $13.9^{\mathrm{ab}}(0.48)$ \\
\hline 1.0 & $485.8^{\mathrm{ab}}(19.8)$ & $280.1^{\mathrm{b}}(22.1)$ & $765.9^{a}(39.6)$ & $16.7^{\mathrm{b}}(0.39)$ & $11.53^{\mathrm{b}}(0.54)$ & $11.78^{\mathrm{b}}(0.43)$ \\
\hline 1.5 & $474.7^{\mathrm{ab}}(16.2)$ & $276.9^{\mathrm{b}}(15.9)$ & $751.6^{\mathrm{a}}(12.9)$ & $22.0^{\mathrm{ab}}(0.34)$ & $7.91^{\mathrm{c}}(0.47)$ & $9.93^{\mathrm{c}}(0.59)$ \\
\hline 2.0 & $450.5^{\mathrm{ab}}(28.9)$ & $293.5^{\mathrm{b}}(15.2)$ & $744.1^{\mathrm{a}}(38.1)$ & $27.9^{\mathrm{a}}(0.27)$ & $5.95^{\mathrm{cd}}(0.32)$ & $8.82^{\mathrm{c}}(0.56)$ \\
\hline
\end{tabular}

Each value is the mean of three replicates; means in the same column followed by the same letter are not significantly different at a $5 \%$ level of significance; the standard error of three replicates is presented in parentheses.

protochlorophyllidine reductase and/or the water-splitting enzyme located at the oxidizing site of photosystem II [4849].

Superoxide dismutase (SOD) Assay: The SOD assay reflects the increase in superoxide dismutase activity with increasing levels of EEO concentration in the soil. The maximum values were observed in the presence of $2 \%$ EEO, whereas lower activity was observed in the control. A detailed description on SOD values is presented in Table 3.

Catalase activity Assay (CAT): The CAT assay elucidates a progressive decrease in the CAT values with increasing stress level due to EEO. The controlled plants exhibited highest CAT contents and the lowest activity was observed at $2 \%$ EEO concentration (Table 3 ). This could be due

Table 4. Residual EEO and phytoremediation.

\begin{tabular}{|c|c|c|c|}
\hline \multirow{2}{*}{$\begin{array}{l}\text { Treatment } \\
(\% \text { EEO })\end{array}$} & \multicolumn{2}{|c|}{$\begin{array}{l}\text { Exhausted Engine Oil } \\
\text { Concentrations }\end{array}$} & \multirow{2}{*}{$\begin{array}{l}\text { Degradation } \\
(\%)\end{array}$} \\
\hline & $\begin{array}{c}\text { Initial } \\
\text { concentration } \\
\text { (grams) }\end{array}$ & $\begin{array}{c}\text { Final } \\
\text { Concentration } \\
\text { (grams) }\end{array}$ & \\
\hline Control & - & - & - \\
\hline 0.5 & $0.76^{\mathrm{d}}(0.04)$ & $0.47^{\mathrm{d}}(0.21)$ & 38.1 \\
\hline 1.0 & $1.34^{\mathrm{de}}(0.02)$ & $0.89^{\mathrm{d}}(0.19)$ & 33.5 \\
\hline 1.5 & $1.97^{\mathrm{de}}(0.07)$ & $1.29^{\mathrm{cd}}(0.24)$ & 34.5 \\
\hline 2.0 & $2.64^{\mathrm{cd}}(0.25)$ & $2.04^{c}(0.26)$ & 22.7 \\
\hline 3.0 & $2.95^{\mathrm{d}}(0.4)$ & $2.38^{\mathrm{c}}(0.31)$ & 19.3 \\
\hline 4.0 & $3.44^{\mathrm{c}}(0.04)$ & $2.78^{\mathrm{c}}(0.22)$ & 19.1 \\
\hline 5.0 & $3.89^{\mathrm{c}}(0.25)$ & $3.16^{\mathrm{bc}}(0.34)$ & 18.7 \\
\hline 7.5 & $5.13^{\mathrm{b}}(0.2)$ & $4.20^{\mathrm{b}}(0.41)$ & 18.1 \\
\hline 10.0 & $6.87^{\mathrm{ab}}(0.41)$ & $5.65^{\mathrm{ab}}(0.34)$ & 17.8 \\
\hline 15.0 & $8.51^{\mathrm{a}}(0.5)$ & $7.04^{\mathrm{a}}(0.42)$ & 17.3 \\
\hline
\end{tabular}

Each value is the mean of three replicates; means in the same column followed by the same letter are not significantly different at a $5 \%$ level of significance; the standard error of three replicates is presented in parentheses. to the stress response of the plant to the increased ROS production [11].

Soluble protein content (SPC): A gradual decrease in soluble protein content was observed with increasing concentration of EEO and the highest value was observed in control soil. Moreover, a statistically significant difference was observed among all treatments (Table 3). The decrease in SPC reflects the degradation of plant enzymes due to hydrocarbon stress as well as disturbed metabolism [50].

Conclusively, EEO treatment increased the SOD activities, leading to a gradual decrease in CAT and SPC content. This finding is broadly consistent with abiotic stress responses caused by excess ROS activity through enzymatic reduction $[26,51]$.

\section{Residual EEO}

Our analysis reveals that maximum EEO removal was observed in soil with its lower concentration, which was later decreased with increases in concentration (Table 4). Similar results were reported by [25], in that Mirabilis jalapa can remove the petroleum hydrocarbons. However, removal efficiency is greatly impacted by the concentration of petroleum contaminants.

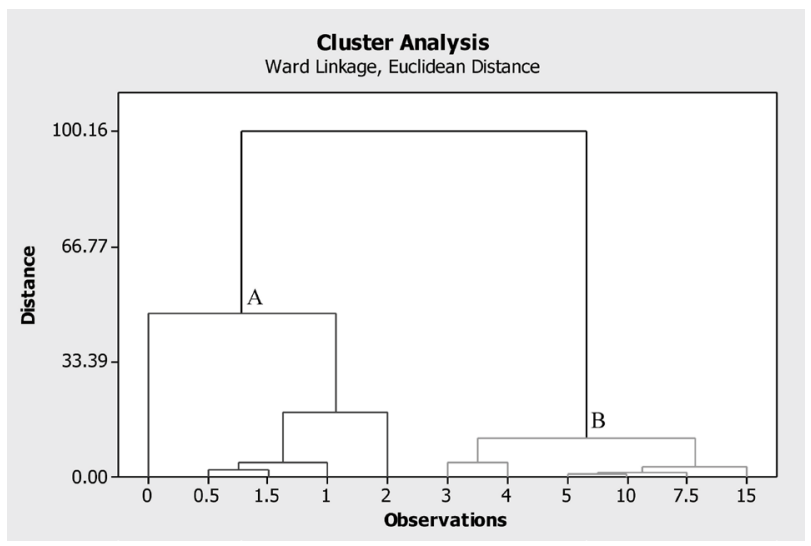

Fig. 1. Classification of the treatments produced by Q-mode cluster analysis using Euclidean distance. 


\section{Cluster Analysis}

Cluster analysis resulted in the grouping of treatments into two main clusters (Fig. 1). Cluster A represent the treatments with lower EEO concentrations (0 to 2.0) and therefore had less toxic effects on the plants, whereas Cluster B groups all had higher concentration treatments (3.0 to 15.0 ) with significantly higher toxicity. The clustering further supports the limitation of biochemical analysis up to $2 \%$ EEO concentration.

\section{Conclusions}

In a nutshell, our study concludes that the increasing concentration of EEO significantly affected plant health (i.e., M. jalapa) in terms of germination rate, plant biomass, chlorophyll content, and production of reactive oxygen species. The high biomass and successful germination rate is observed in the plants grown at lower EEO concentrations (i.e., $<2 \%$ ) compared to the plants grown at higher concentrations (i.e., $>2 \%$ ). The finding is further confirmed with enzymatic assays indicating the presence of high reactive oxygen species. Finally, the study confirms the toxic nature of EEO, and the results reflect that the plant is least suitable for phytoremediation of EEO but, in future, may be considered with improved phytotechnologies, i.e., a plant-bacteria partnership (rhizobacteria and endophytic bacteria) $[12,39,52]$.

\section{References}

1. ABIOYE P.O., AZIZ A.A., AGAMUTHU P. Enhanced biodegradation of used engine oil in soil amended with organic wastes. Water Air Soil Pollut. 209 (1-4), 173, 2010.

2. OSUJI L. C.,NWOYE I. An appraisal of the impact of petroleum hydrocarbons on soil fertility: the Owaza experience. Afr. J. Agric. Res. 2 (7), 318, 2007.

3. FUENTES M., FONT R., GÓMEZ-RICO M., MARTÍNGULLÓN I. Pyrolysis and combustion of waste lubricant oil from diesel cars: decomposition and pollutants. J. Anal. Appl. Pyrolysis. 79 (1), 215, 2007.

4. LAM S.S., RUSSELL A.D., CHASE H.A. Microwave pyrolysis, a novel process for recycling waste automotive engine oil. Energy. 35 (7), 2985, 2010.

5. LAM S.S., RUSSELL A.D., LEE C.L., CHASE H.A. Microwave-heated pyrolysis of waste automotive engine oil: Influence of operation parameters on the yield, composition, and fuel properties of pyrolysis oil. Fuel. 92 (1), 327, 2012.

6. LAPINSKIENĖ A., MARTINKUS P., RĖBŽDAITĖ V. Ecotoxicological studies of diesel and biodiesel fuels in aerated soil. Environ. Pollut. 142 (3), 432, 2006.

7. OLOLADE I. Prediction of polycyclic aromatic hydrocarbons toxicity using equilibrium partitioning approach and narcosis model. Bull. Environ. Contam. Toxicol. 85 (3), 238, 2010.

8. ARSLAN M., IMRAN A., KHAN Q. M., AFZAL M. Plant-bacteria partnerships for the remediation of persistent organic pollutants. Environ. Sci. Pollut. Res. 1-15, 2015.

9. YEBRA-PIMENTEL I., FERNÁNDEZ-GONZÁLEZ R., MARTÍNEZ-CARBALLO E., SIMAL-GÁNDARA J. A critical review about the health risk assessment of PAHs and their metabolites in foods. Crit. Rev. Food Sci. Nutr. 55 (10), 1383, 2015.

10. BAIRD C.,CANN M. PESTICIDES. IN FIORILLO J., TREADWAY K., WEISS V., (Eds.) Environmental chemistry. 415. 2005

11. LI W., XU B., SONG Q., LIU X., XU J., BROOKES P.C. The identification of 'hotspots' of heavy metal pollution in soil-rice systems at a regional scale in eastern China. Sci. Total. Environ. 472, 407, 2014.

12. KHAN M.U., SESSITSCH A., HARRIS M., FATIMA K., IMRAN A., ARSLAN M., SHABIR G., KHAN Q.M., AFZAL M. Cr-resistant rhizo-and endophytic bacteria associated with Prosopis juliflora and their potential as phytoremediation enhancing agents in metal-degraded soils. Front. Plant Sci. 5 (755), 10.3389, 2015.

13. KHAN S., AFZAL M., IQBAL S., KHAN Q.M. Plantbacteria partnerships for the remediation of hydrocarbon contaminated soils. Chemosphere. 90 (4), 1317, 2013.

14. BATTY L.C., DOLAN C. The potential use of phytoremediation for sites with mixed organic and inorganic contamination. Crit. Rev. Environ. Sci. Technol. 43 (3), 217, 2013.

15. CHEN L., LIU X., ZHANG X., LIU S., WEI J., XU G. Response characteristics of seed germination and seedling growth of Acorus tatarinowii under diesel stress. Plant Soil. 368 (1-2), 355, 2013.

16. BAEK K.-H., KIM H.-S., OH H.-M., YOON B.-D., KIM J., LEE I.-S. Effects of crude oil, oil components, and bioremediation on plant growth. J. Environ. Sci. Health. Part A. 39 (9), $2465,2004$.

17. MOLINA-BARAHONA L., VEGA-LOYO L., GUERRERO M., RAMIREZ S., ROMERO I., VEGA-JARQUÍN C., ALBORES A. Ecotoxicological evaluation of dieselcontaminated soil before and after a bioremediation process. Environ. Toxicol. 20 (1), 100, 2005.

18. ZHANG X., LIU X., LIU S., LIU F., CHEN L., XU G., ZHONG C., SU P., CAO Z. Responses of Scirpus triqueter, soil enzymes and microbial community during phytoremediation of pyrene contaminated soil in simulated wetland. J. Hazard. Mater. 193, 45, 2011.

19. KAUR N., GUPTAA.K. Signal transduction pathways under abiotic stresses in plants. Curr. Sci. 88 (11), 1771, 2005.

20. SHAHID M., DUMAT C., POURRUT B., ABBAS G., SHAHID N., PINELLI E. Role of metal speciation in leadinduced oxidative stress to Vicia faba roots. Russ. J. Plant Physl. 62 (4), 448, 2015.

21. ÜNYAYAR S., ÇELIK A., ÇEKIÇ F. Ö., GÖZEL A. Cadmium-induced genotoxicity, cytotoxicity and lipid peroxidation in Allium sativum and Vicia faba. Mutagenesis. 21 (1), 77, 2006.

22. MØLLER I. M., JENSEN P. E., HANSSON A. Oxidative modifications to cellular components in plants. Annu. Rev. Plant Biol. 58, 459, 2007.

23. ZHOU Q., DIAO C., SUN Y., ZHOU J. Tolerance, uptake and removal of nitrobenzene by a newly-found remediation species Mirabilis jalapa L. Chemosphere. 86 (10), 994, 2012.

24. CAOA., CARUCCIA., LAI T., LA COLLAP., TAMBURINI E. Effect of biodegradable chelating agents on heavy metals phytoextraction with Mirabilis jalapa and on its associated bacteria. Eur. J. Soil Biol. 43 (4), 200, 2007.

25. PENG S., ZHOU Q., CAI Z., ZHANG Z. Phytoremediation of petroleum contaminated soils by Mirabilis Jalapa L. in a greenhouse plot experiment. J. Hazard. Mater. 168 (2), 1490, 2009.

26. LIU F., YING G.-G., TAO R., ZHAO J.-L., YANG J.-F., ZHAO L.-F. Effects of six selected antibiotics on plant 
growth and soil microbial and enzymatic activities. Environ. Pollut. 157 (5), 1636, 2009.

27. WEI X., WU S., NIE X., YEDILER A., WONG M. The effects of residual tetracycline on soil enzymatic activities and plant growth. J. Env. Sci. Health. Part B. 44 (5), 461, 2009.

28. AFZAL M., YOUSAF S., REICHENAUER T. G., SESSITSCH A. The inoculation method affects colonization and performance of bacterial inoculant strains in the phytoremediation of soil contaminated with diesel oil. Int. J. Phytoremediation. 14 (1), 35, 2012.

29. ABRÀMOFF M.D., MAGALHÃES P.J., RAM S.J. Image processing with ImageJ. Biophoton. Int. 11 (7), 36, 2004.

30. MEHMOOD R., RIAZ M., DOES R.J. Control charts for location based on different sampling schemes. J. of Appl. Stat. 40 (3), 483, 2013.

31. PATIL G., SINHA A., TAILLIE C. 5 Ranked set sampling. Handbook of statistics. 12, 167, 1994.

32. ODJEGBA V.,FASIDI I. Accumulation of trace elements by Pistia stratiotes: implications for phytoremediation. Ecotoxicology. 13 (7), 637, 2004.

33. AFZAL M., KHAN S., IQBAL S., MIRZA M. S., KHAN Q.M. Inoculation method affects colonization and activity of Burkholderia phytofirmans PsJN during phytoremediation of diesel-contaminated soil. Int. Biodeterior. Biodegrad. 85, 331, 2013.

34. GULEN H.,ERIS A. Effect of heat stress on peroxidase activity and total protein content in strawberry plants. Plant Sci. 166 (3), 739, 2004.

35. SHANGARI N., O'BRIEN P.J. Catalase activity assays. Curr. Protoc. Toxicol. 7.7. 1-7.7. 16, 2006.

36. BANNISTER J. V.,CALABRESE L. Assays for superoxide dismutase. Method. Biochem. Anal. 32, 279, 2006.

37. LICHTENTHALER H. K.,BUSCHMANN C. Chlorophylls and carotenoids: Measurement and characterization by UVVIS spectroscopy. Current Protocols in Food Analytical Chemistry. 2001.

38. RIAZ M., MAHMOOD T., ARSLAN M. Non-Parametric versus Parametric Methods in Environmental Sciences. Bullet. Environ. Stud. 1 (1), 28, 2016.

39. ARSLAN M., AFZAL M., AMIN I., IQBAL S., KHAN Q.M. Nutrients can enhance the abundance and expression of alkane hydroxylase CYP153 gene in the rhizosphere of ryegrass planted in hydrocarbon-polluted soil. PloS ONE. 9 (10), e111208, 2014.

40. BONA C., REZENDE I.M.D., SANTOS G.D.O., SOUZA L.A.D. Effect of soil contaminated by diesel oil on the germination of seeds and the growth of Schinus terebinthifolius Raddi (Anacardiaceae) Seedlings. Braz. Arch. Biol. Technol. 54 (6), 1379, 2011.

41. SOBRERO M. C.,RONCO A. Ensayo de toxicidad aguda con semillas de lechuga (Lactuca sativa L.). Ensayos toxicológicos y métodos de evaluación de calidad de aguas. IDRC/IMTA. Canadá, Capítulo. 4, 71, 2004.

42. ADENIPEKUN C.O., OYETUNJI O.J., KASSIM L.S. Effect of spent engine oil on the growth parameters and chlorophyll content of Corchorus olitorius Linn. The Environmentalist. 28 (4), 446, 2008.

43. AGBOGIDI O., ERUOTOR P. Morphological changes due to spent engine oil contamination and its heavy metal components of Jatropha curcas Linn. seedlings. Proceedings of the International on Bioscience Biotechnology and Health care Sciences (ICBBHS. 2012) held in Singapore between $14^{\text {th }}$ and $15^{\text {th }}$ of. $88,2012$.

44. SHARIFI M., SADEGHI Y., AKBARPOUR M. Germination and growth of six plant species on contaminated soil with spent oil. Int. J. Env. Sci. Tech. 4 (4), 463, 2007.

45. VWIOKO D., FASHEMI D. Growth response of Ricinus communis L (Castor Oil) in spent lubricating oil polluted soil. J. Appl. Sci. Environ. Mgt. 9 (2), 73, 2005.

46. AGBOGIDI O., OHWO A. Trace metal profile of Moringa oleifera (Linn.) seedlings sown in spent lubricating oil contaminated soils. J. Curr. Res. Sci. 1 (4), 242, 2013.

47. NWOKO C., OKEKE P., AGWU O., AKPAN I. Performance of Phaseolus vulgaris L. in a soil contaminated with spentengine oil. Afr. J. Biotech. 6 (16), 2007.

48. SHEIKH S.A., TAK M.A., WANI M.R., AHMAD P. Response of urdbean (vigna mungo (1.) Hepper) in terms of growth, yield and biochemical parameters to spent engine oil pollution. J. Appl. Phytotechnol. Environ. Sanit. 2 (4), 2013.

49. VAN ASSCHE F.,CLIJSTERS H. A biological test system for the evaluation of the phytotoxicity of metal-contaminated soils. Environ. Pollut. 66 (2), 157, 1990.

50. OLUBODUN O.S., ERIYAMREMU E.G. Effect of Different Crude Oil Fractions on Growth and Oxidative Stress Parameters of Maize Radicle. Int. J. Plant Soil Sci. 2 (1), 144, 2013.

51. LIU H., WEISMAN D., YE Y.-B., CUI B., HUANG Y.-H., COLÓN-CARMONA A., WANG Z.-H. An oxidative stress response to polycyclic aromatic hydrocarbon exposure is rapid and complex in Arabidopsis thaliana. Plant Sci. 176 (3), 375, 2009.

52. IJAZ A., IMRAN A., UL HAQ M.A., KHAN Q.M., AFZAL M. Phytoremediation: recent advances in plant-endophytic synergistic interactions. Plant Soil. 1-17, 2015. 